\title{
PATRIOTYZM, HOMOFOBIA I NIETOLERANCJA A WIZERUNEK SPOŁECZNOŚCI LGBT+ W POLSKICH TYGODNIKACH KATOLICKICH W KONTEKŚCIE MARSZÓW RÓWNOŚCI W 2019 R.
}

\author{
Rafał Leśniczak \\ (iD) orcid.org/0000-0003-0099-4327 \\ Uniwersytet Kardynała Stefana Wyszyńskiego w Warszawie
}

\begin{abstract}
Patriotism, Homophobia, and Intolerance and the Image of the LGBT+ Community in Polish Catholic Weeklies in the Context of Equality Marches in 2019

The purpose of the research was to analyze the image of the LGBT+ community in nationwide Catholic weeklies published in Poland, in particular in the context of patriotism, homophobia, and intolerance. Equality marches in 2019 constituted an important framework of the analysis. The author's intention was also to determine which of the attitudes towards the principle of equality of each person before the law regardless of sexual orientation (acceptance vs. criticism) dominated in the individual press titles. The research material consisted of printed versions of four Catholic weekly magazines: Niedziela, Gość Niedzielny, Idziemy and Tygodnik Powszechny. The analysis covered texts about the LGBT+ community, which contained at least one of the following keywords: LGBT; Equality march; Equality parade, which was published in the period between March 31st, 2019 and September 30th, 2019. The author used the method of press content analysis and the method of qualitative discourse analysis. The results of the analyses showed that the LGBT+ community had an important place in Polish Catholic weekly magazines. Niedziela, Gość Niedzielny, and Idziemy have explicitly criticized LGBT ideology and have portrayed LGBT+ persons as intolerant, and their opponents as patriotic. Tygodnik Powszechny has distanced itself from attributing intolerant attitudes to the LGBT+ community, while imposing a homophobic attitude towards its opponents. The research has shown different press images of people belonging to sexual minorities in Catholic right-wing conservative weeklies and those press titles which represent the so-called open church. The different understanding of the sacred/profane categories, religious symbols as well as cultural dimensions of sexual revolution, found in the analysed press titles, along with different uses of mediatization metaphors for the critics of LGBT+ community, contributed to the bipolarity of the narratives explored in this article.
\end{abstract}

Keywords: patriotism, homophobia, intolerance, image, LGBT+ community, Catholic press 


\section{Wprowadzenie}

Artykuł jest próbą określenia wizerunku środowiska LGBT+ w ogólnopolskich tygodnikach katolickich, w szczególności oceny stopnia obecności kategorii patriotyzmu i nietolerancji, które zostały tym periodykom przypisane, oraz kategorii patriotyzmu i homofobii adresowanych w stosunku do oponentów LGBT+ drukujących w tych czasopismach. Kontekst analizy prasoznawczej stanowiły marsze równości w 2019 r., których organizatorami były osoby przynależące do mniejszości seksualnych. Zagadnienia dotyczące środowisk LGBT+ są przedmiotem zainteresowań naukowych socjologów, kulturoznawców, politologów i teologów (Gegenfurtner, Gebhardt 2017, s. 215-222; Bilić, Kajinić 2016; Nadar, van Klinken 2018, s. 101-109). Nieliczne jednak okazują się analizy medioznawcze podejmujące temat wizerunku środowiska LGBT+ w katolickiej prasie polskiej (Pokorna-Ignatowicz 2014, s. 194-251; Kościółek, Bulandra, Zimnoch 2015). Zamiarem autora prezentowanych rozważań było również ustalenie, która z postaw (akceptacja albo krytyka), dotycząca fundamentów zasady równości każdego człowieka wobec prawa, niezależnie od jego orientacji seksualnej, dominowała w poszczególnych tytułach prasowych.

W pierwszej części artykułu zostanie wyjaśnione rozumienie kategorii patriotyzmu, homofobii i nietolerancji oraz zaprezentowane stanowisko Kościoła katolickiego na temat środowiska LGBT+. Druga część publikacji ma charakter metodologiczny. Prezentuje hipotezę badawczą oraz wykorzystany w badaniach prasoznawczych klucz kategoryzacyjny. W trzeciej części artykułu przedstawiono wyniki analizy i zweryfikowano hipotezy badawcze. Artykuł kończy podsumowanie. Przyjęto założenie, że prasa katolicka będzie realizować nauczanie Kościoła katolickiego, tzn. wspierać postawę patriotyzmu, tolerancji i szacunku dla osób przynależących do mniejszości seksualnych, natomiast sprzeciwiać się nierespektowaniu zasady równości człowieka wobec prawa, która byłaby zależna od jego orientacji seksualnej.

\section{Kategorie patriotyzmu, homofobii i nietolerancji. Katolicka nauka społeczna na temat środowiska LGBT+}

Patriotyzm jest postawą społeczno-polityczną stawiającą wysoko w hierarchii wartości dobro własnego narodu i ojczyzny, ale jednocześnie wiąże się on z uznaniem innych wartości społecznych: wyraża szacunek wobec odmiennych narodów i ich suwerennych praw. Dobra wspólnoty narodowej, takie jak: kultura, etos, dzieje, religijność, terytorium, są składnikami pojęcia ojczyzny (Skorowski 1996, s. 140-145; Tytko 2013, s. 213-223; Przesmycki 2008, s. 198-200).

Postawę patriotyczną cechuje respektowanie godności każdego człowieka (Sienkiewicz 2007, s. 35-54), dlatego patriotyzm wyraża szacunek i tolerancję m.in. wobec osób należących do mniejszości seksualnych, migrantów czy uchodźców. Postawę patriotyzmu autor traktuje jako aktywne i twórcze uczestnictwo w procesie otwierania się na innych, jako poczucie dumy z przynależności do określonej 
społeczności oraz możliwości poznania i zrozumienia innych kultur. A zatem jest to postawa dialogu, tolerancji i szacunku dla drugiej osoby (Nikitorowicz 2013, s. 18).

Jak zauważa Andrzej Antoszewski, w aksjologii demokratycznej podstawowymi wartościami są wolność i godność człowieka, zaś w koncepcji civil society wyeksponowane zostają postawy otwarte, inkluzywne, pluralistyczne i tolerancyjne (Antoszewski 2000, s. 14; Antoszewski 2004, s. 66). W Polsce jako kraju demokratycznym i w społeczeństwie polskim uznawanym za obywatelskie (Podemski 2014, s. 89-109; Kinowska 2012, s. 1-4), postawy respektowania godności każdego człowieka powinny stanowić pewien przyjęty przez wszystkich obywateli standard zachowań i postaw.

Dokument Konferencji Episkopatu Polski przygotowany przez Radę ds. Społecznych z 14 marca 2017 r., zatytułowany „Chrześcijański kształt patriotyzmu”, przypomina, że patriotyzm głęboko wpisuje się w uniwersalny nakaz miłości bliźniego, jest obowiązkiem chrześcijańskim i wiąże się z nakazem czwartego przykazania Bożego (Rada ds. Społecznych KEP). Chrześcijańska wizja patriotyzmu chroni od obojętności na losy drugich, uwrażliwia na potrzeby każdego człowieka, bez względu na to, jakim językiem mówi i jakie ma poczucie narodowe (Rada ds. Społecznych KEP, p. 1). Biskupi polscy podkreślają, że „dojrzały patriotyzm rozumiany jako miłość bliźniego, solidarność, odpowiedzialność za los konkretnych ludzi, otwartość na współpracę z innymi, zdaje się być we współczesnym świecie jedną z recept na uczucia lęku, zagubienia i zagrożenia, którymi żywi się wiele ideologii - takich, które odrzucają istnienie więzi międzyludzkich, redukując człowieka do odizolowanego od innych indywiduum i takich, które odwołują się do języka nacjonalizmu” (Rada ds. Społecznych KEP, p. 2). Biskupi napisali, że patriotycznym obowiązkiem jest też

angażowanie się w dzieło społecznego pojednania poprzez przypominanie prawdy o godności każdego człowieka, łagodzenie nadmiernych politycznych emocji, wskazywanie i poszerzanie pól możliwej i niezbędnej dla Polski współpracy ponad podziałami oraz ochrona życia publicznego przed zbędnym upolitycznianiem. A pierwszym krokiem, który w tej patriotycznej posłudze trzeba uczynić, jest refleksja nad językiem, jakim opisujemy naszą ojczyznę, współobywateli i nas samych (Rada ds. Społecznych KEP, s. 4).

Homofobia jest lękiem przed bliskim kontaktem z ludźmi homoseksualnymi i pogardą w stosunku do nich (Madžarević, Soto-Sanfiel 2018, s. 910). Termin ten odnosi się do szerokiego zakresu postaw i zachowań, z którymi związane są negatywne uczucia wobec osób homoseksualnych. Zachowania homofobiczne cechuje lęk, niepokój, gniew, poczucie dyskomfortu psychicznego i awersja, których osoba doświadcza w zetknięciu z osobami o orientacji homoseksualnej (Herek 2007, s. 905-925).

Nauczanie Kościoła katolickiego dotyczące zagadnienia homoseksualizmu cechuje postawa szacunku dla osób homoseksualnych i zrozumienia ich potrzeb duszpasterskich. Kościół negatywnie ocenia jednak same czyny homoseksualne, które definiuje jako nieuporządkowane wewnętrznie. Apeluje on do osób należących 
do tzw. mniejszości seksualnych o wstrzemięźliwość, a do społeczeństwa o postawę tolerancji i respektowania odmienności (Augustyn 2007, s. 10-15; Bujak 2014, s. 71-72; Przeciszewski 2019).

Kategorię nietolerancji autor rozumie jako postawę braku akceptacji i zgody na odmienność opinii, myśli i wiary oraz odcięcie się od dialogu z zamiarem przezwyciężenia wymienionych odmienności (Glombik 2013, s. 114). Zagadnienie tolerancji w niniejszych rozważaniach zostało odniesione do ludzi i grup charakteryzujących się odrębną przynależnością religijną, światopoglądową lub przyznających się do inności w zakresie zachowań seksualnych (Glombik 2013, s. 113).

Opisane wyżej kategorie patriotyzmu, homofobii i nietolerancji przyjęto jako obowiązujące w podjętej analizie prasoznawczej.

Krótkiego omówienia domaga się również stanowisko Kościoła katolickiego wobec środowiska LGBT+. Można bowiem przyjąć, że analizowane tytuły prasowe ze względu na swój profil powinny odzwierciedlać oficjalne nauczanie instytucji eklezjalnej. W sposób przystępny i zwięzły stanowisko instytucji kościelnej w tej kwestii wyraża oświadczenie abp. Stanisława Gądeckiego w sprawie LGBT+:

Osoby przynależące do środowisk tzw. mniejszości seksualnych są naszymi braćmi i siostrami, za których Chrystus oddał swoje życie i które również chce doprowadzić do zbawienia. Szacunek dla konkretnych osób nie może jednak prowadzić do akceptacji ideologii, która stawia sobie za cel przeprowadzenie rewolucji w zakresie społecznych obyczajów i międzyosobowych relacji (Gądecki 2019).

Podobnie traktuje tę problematykę Katechizm Kościoła Katolickiego (KKK) w punktach 2357-2359, w których podejmuje temat czystości i homoseksualizmu:

Tradycja, opierając się na Piśmie świętym, przedstawiającym homoseksualizm jako poważne zepsucie, zawsze głosiła, że akty homoseksualizmu z samej swojej wewnętrznej natury są nieuporządkowane. Są one sprzeczne z prawem naturalnym; wykluczają z aktu płciowego dar życia. Nie wynikają z prawdziwej komplementarności uczuciowej i płciowej. W żadnym wypadku nie będą mogły zostać zaaprobowane (KKK 2357). Pewna liczba mężczyzn i kobiet przejawia głęboko osadzone skłonności homoseksualne. Skłonność taka, obiektywnie nieuporządkowana, dla większości z nich stanowi trudne doświadczenie. Powinno się traktować te osoby z szacunkiem, współczuciem i delikatnością. Powinno się unikać wobec nich jakichkolwiek oznak niesłusznej dyskryminacji [...] (KKK 2358). Osoby homoseksualne są wezwane do czystości. Dzięki cnotom panowania nad sobą, które uczą wolności wewnętrznej, niekiedy dzięki wsparciu bezinteresownej przyjaźni, przez modlitwę i łaskę sakramentalną, mogą i powinny przybliżać się one - stopniowo i zdecydowanie - do doskonałości chrześcijańskiej (KKK 2359). 


\section{Metodologia badań}

Celem podjętej analizy było określenie wizerunku środowiska LGBT+ w ogólnopolskiej prasie katolickiej, w szczególności opisanie stopnia przyporządkowania przez autorów tekstów prasowych kategorii patriotyzmu i nietolerancji osobom należącym do mniejszości seksualnych oraz kategorii patriotyzmu i homofobii oponentom LGBT+. Podjęto również próbę ustalenia, która z postaw równości każdego człowieka wobec prawa niezależnie od jego orientacji seksualnej (akceptacja vs. krytyka) dominowała w poszczególnych tytułach prasowych.

Autor przyjął następującą hipotezę badawczą, złożoną z pięciu tez H1-H5.

- H1: Temat środowiska LGBT+ zajmował ważne miejsce w polskich tygodnikach katolickich ${ }^{1}$.

- H2: Głównymi protagonistami publikacji byli publicyści katoliccy i teolodzy wypowiadający się na temat ideologii $\mathrm{LGBT}^{2}$.

- H3: Tytuły polskich tygodników katolickich Niedziela, Gość Niedzielny oraz Idziemy przypisały środowisku LGBT+ cechy nietolerancyjne, zaś Tygodnik Powszechny - cechy zarówno patriotyczne, jak i nietolerancyjne ${ }^{3}$.

- H4: Tytuły polskich tygodników katolickich Niedziela, Gość Niedzielny oraz Idziemy przypisały przeciwnikom LGBT+ cechy patriotyczne, zaś Tygodnik Powszechny - cechy zarówno patriotyczne, jak i homofobiczne.

- H5: Autorzy tekstów prasowych wszystkich analizowanych katolickich tytułów prasowych przyjęli postawę krytyki wobec ideologii LGBT ${ }^{4}$.

1 Hipotezę kierunkową H1 potwierdzają dotychczasowe badania nad miejscem społeczności i ideologii LGBT w polskim dyskursie publicznym oraz wyrażane stanowisko Kościoła katolickiego w tej kwestii. Por. np. Graff 2014, s. 431-435; Szwed, Zielińska 2017, s. 113-136; Hall 2016. Celem weryfikacji hipotezy H1 wyodrębniono w kluczu kategoryzacyjnym dwie cechy: EKSPOZYCYJNOŚĆ i WIELKOŚĆ.

2 Hipoteza kierunkowa $\mathrm{H} 2$ wynika z profilu analizowanych tygodników. Można domniemywać, że w dyskusji na temat kwestii światopoglądowej w prasie katolickiej zostaje wyeksponowany katolicki punkt widzenia.

3 Hipotezy kierunkowe H3 i H4 wynikają z dotychczasowych badań nad polską prasą katolicką, w której Niedziela, Gość Niedzielny oraz Idziemy mają charakter prawicowo-konserwatywny, zaś Tygodnik Powszechny reprezentuje tzw. katolicyzm otwarty i promuje liberalny nurt katolicyzmu. Należy ponadto zauważyć, że pierwsze trzy tytuły prasowe reprezentują stanowisko instytucjonalnego Kościoła katolickiego (organy diecezjalne i/lub posiadające asystenta kościelnego). Tygodnik Powszechny jest „katolicki”, ale formalnie nie ma nic wspólnego z kościołem hierarchicznym, nie reprezentuje bowiem stanowiska episkopatu ani żadnych władz czy struktur kościelnych. Por. Leśniczak 2017, s. 299-318; Tasak 2014, s. 76-80; Delong 2007, s. 56-64; Leśniczak 2018, s. 37-56.

4 Hipoteza kierunkowa H5 wynika z oficjalnego nauczania Kościoła w kwestii ideologii LGBT. 
Celem weryfikacji hipotezy badawczej skonstruowano klucz kategoryzacyjny, wskazując w ramach badanych cech precyzyjnie zdefiniowane kategorie o charakterze rozłącznym ${ }^{5}$.

Wyodrębniono następujące cechy badawcze: EKSPOZYCYJNOŚĆ, WIELKOŚĆ, PROTAGONIŚCI, ŚRODOWISKO LGBT+, OPONENCI, IDEOLOGIA LGBT.

I. Badana cecha: EKSPOZYCYJNOŚĆ - miejsce w tygodniku, w którym zamieszczono publikację prasową dotyczącą środowiska LGBT+.

Kategorie w ramach badanej cechy:

1. I rzędu - publikacja znajduje się na okładce, na pierwszych trzech stronach lub w najważniejszej części danej edycji tygodnika (np. „Temat numeru”);

2. II rzędu - publikacja znajduje się w innych miejscach niż wskazano w kategorii I rzędu.

II. Badana cecha: WIELKOŚĆ - cecha określająca orientacyjną powierzchnię zajmowaną przez materiał poddany badaniom.

Kategorie w ramach badanej cechy:

1. mała - materiał mniejszy niż $1 / 2$ strony;

2. średnia: materiał nie mniejszy niż $1 / 2$ strony, ale nie większy niż 1 strona;

3. duża: materiał mający powierzchnię przynajmniej jednej strony.

III. Badana cecha: PROTAGONIŚCI - kluczowe, najważniejsze postacie występujące w tekście prasowym (wokół nich koncentruje się temat dyskursu i ich sylwetki zostają najbardziej wyeksponowane przez autora tekstu).

Kategorie w ramach badanej cechy:

1. publicysta katolicki - autor publikacji prasowej podejmujący temat ideologii LGBT $^{\mathbf{6}}$;

5 Każda z publikacji prasowych została przypisana wyłącznie do jednej kategorii w ramach poszczególnych cech klucza kategoryzacyjnego.

6 W podjętych badaniach zastosowano skrótowiec „LGBT+” na określenie populacji osób nieheteronormatywnych (Müller 2018, s. 14-27). Posłużono się terminem „ideologia LGBT”, który dość rzadko pojawia się w literaturze naukowej przedmiotu (Czupryński 2019, s. 455-469), bywa on traktowany jako medialna klisza językowa stosowana w odniesieniu do zbioru poglądów służących całościowemu interpretowaniu i przekształcaniu świata (Korolczuk 2019, s. 165-167). Badania populacji LGBT+ dowodzą ogromnej jej różnorodności w zakresie postaw dotyczących ważnych kwestii społecznych (włącznie z tym, że wiele badanych osób LGBT+ w ogóle nie widzi potrzeby politycznego lobbingu na rzecz równości, ma zróżnicowany stosunek do religii, popiera różne partie polityczne). Nie ma zatem mowy, poza prawicowym dyskursem medialnym kreującym mityczne zagrożenie „ideologią LGBT”, o jakiejkolwiek spójnej interpretacji i chęci przekształcania świata kreowanej przez osoby LGBT+. Przyjąć można co najwyżej, że duża część tej populacji, na czele z aktywistami i aktywistkami zorganizowanymi w organizacjach i ruchach społecznych, zgadza się z fundamentami ideologii praw człowieka, zwłaszcza z zasadą równości każdego człowieka wobec prawa niezależnie od jego orientacji seksualnej. Tylko w tym znaczeniu przekaz ruchów i organizacji na rzecz 
2. reprezentant środowiska LGBT+ - np. organizator lub uczestnik marszu równości bądź inna osoba wspierająca ideologię LGBT;

3. oponent - osoba/instytucja nieakceptująca poglądów środowiska LGBT+ i niebędąca autorem publikacji prasowej;

4. żadna $\mathrm{z}$ powyższych.

IV. Badana cecha: ŚRODOWISKO LGBT+ - kategoria przypisana środowisku LGBT+ przez autorów publikacji prasowych (kategorie w niniejszej cesze nie odnoszą się do ideologii LGBT, ale do osób).

Kategorie w ramach badanej cechy:

1. patriotyczna - kategoria patriotyzmu jest wyłączną bądź dominującą kategorią przypisaną środowisku LGBT+;

2. patriotyczna i nietolerancyjna - jednocześnie kategoria patriotyzmu i kategoria nietolerancji zostały przypisane środowisku LGBT+, ale żadna z nich nie dominuje;

3. nietolerancyjna - kategoria nietolerancji jest wyłączną bądź dominującą kategorią przypisaną środowisku LGBT+;

4. żadna z powyższych - brak asocjacji kategorii patriotyzmu i nietolerancji ze środowiskiem LGBT+ lub badana cecha zostaje pominięta.

V. Badana cecha: OPONENCI - kategoria przypisana oponentom środowiska LGBT+ przez autorów publikacji prasowych.

Kategorie w ramach badanej cechy:

1. patriotyczna - kategoria patriotyzmu jest wyłączną bądź dominującą kategorią przypisaną oponentom środowiska LGBT+;

2. patriotyczna i homofobiczna - jednocześnie kategoria patriotyzmu i kategoria homofobii zostały przypisane oponentom środowiska LGBT+, ale żadna $\mathrm{z}$ nich nie dominuje;

3. homofobiczna - kategoria homofobii jest wyłączną bądź dominującą kategorią przypisaną oponentom środowiska LGBT+;

4. żadna z powyższych - brak asocjacji kategorii patriotyzmu i homofobii $\mathrm{z}$ oponentami marszu lub kwestia oponentów zostaje pominięta.

VI. Badana cecha: IDEOLOGIA LGBT - sposób prezentacji ideologii LGBT w tekście prasowym przez jej autora.

Kategorie w ramach badanej cechy:

1. akceptacja - aprobujące stanowisko autora tekstu wobec ideologii LGBT;

2. krytyka - brak akceptacji autora tekstu dla ideologii LGBT;

3. akceptacja i krytyka - jednocześnie aprobata i krytyka ideologii LGBT;

4. żadna $\mathrm{z}$ powyższych - trudno określić stanowisko autora wobec ideologii LGBT albo brak oceny autora. 
W badaniach, które miały charakter ilościowy i jakościowy, posłużono się metodą analizy zawartości prasowej oraz metodą jakościowej analizy dyskursu (Pisarek 1983; Wodak 2011, s. 11-48; Mautner 2011, s. 51-85).

W badaniach nad dyskursem dokonano próby uwzględnienia kontekstu publikacji, intertekstualności, intencjonalności twórców tekstów, informacyjności i sytuacyjności, a zatem kryteriów o charakterze zewnątrztekstowym (Wodak 2011, s. 21).

Jednostkę analizy stanowiła jedna publikacja prasowa. Materiał badawczy obejmował drukowane wersje następujących tytułów prasowych: Niedzieli, Gościa Niedzielnego, Tygodnika Powszechnego, Idziemy ${ }^{7}$, w których zawarte było przynajmniej jedno z następujących słów/wyrażeń kluczowych: „LGBT”, „marsz równości”, "parada równości” i w których podjęto temat środowiska LGBT+. Ramy czasowe badań obejmowały okres od 31 marca do 30 września 2019 roku i pozostawały zbieżne z kalendarzem marszów opublikowanym na stronie „Parada i Marsze Równości 2019” https://mnw.org.pl/parada-i-marsze-rownosci-2019/.

Na podstawie otrzymanych rezultatów badawczych spróbowano określić częstotliwość i ekspozycyjność podejmowanego tematu w poszczególnych tytułach prasowych. Badania objęły także próbę odpowiedzi na pytania, kto (środowisko LGBT+ vs. jego przeciwnicy) zajmował centralne miejsce w relacjach analizowanych tekstów prasowych oraz czy przedstawicielom środowiska LGBT+ została przypisana postawa patriotyzmu/nietolerancji, zaś jego oponentom kategoria patriotyzmu/homofobii.

\section{Wyniki analizy $i$ weryfikacja hipotez badawczych}

Kryteria analizy spełniło łącznie 54 tekstów prasowych, z czego 9 opublikowano w Gościu Niedzielnym, 8 - w Tygodniku Powszechnym, 21 - w Idziemy oraz 16 - w Niedzieli. Środowisko LGBT+ stało się istotnym tematem agendy medialnej. Żaden z tygodników katolickich nie pominął kwestii osób należących do mniejszości seksualnych. Analizowany temat został najbardziej wyeksponowany w tygodnikach Gość Niedzielny i Niedziela - odsetek publikacji zaklasyfikowanych do kategorii I rzędu wynosił odpowiednio 33,33\% i 31,25\%. W Idziemy i w Niedzieli odnotowano największą liczbę tekstów dotyczących środowiska LGBT+ - odpowiednio 21 i 16. We wszystkich analizowanych tytułach prasowych dominowały teksty prasowe zaklasyfikowane do kategorii „średnia” i „duża” w badanej cesze WIELKOŚCI. Można zatem skonstatować, że temat środowiska LGBT+ zajmował ważne miejsce w polskich tygodnikach katolickich. To potwierdza prawdziwość tezy H1.

Badania prasoznawcze potwierdziły także autentyczność tezy H2. Głównymi protagonistami publikacji we wszystkich analizowanych tygodnikach byli publicyści katoliccy i teolodzy wypowiadający się na temat ideologii LGBT - odnotowano to w 33 publikacjach prasowych. Kluczowymi postaciami tekstów prasowych

7 W tekście zastosowano następujące skróty: Niedziela - Nd, Gość Niedzielny - GN, Tygodnik Powszechny - TP, Idziemy - Idz. 
byli najczęściej redaktorzy naczelni lub publicyści związani z redakcją: w Gościu Niedzielnym - Bogumił Łoziński, w Tygodniku Powszechnym - Piotr Wilczyński, w Idziemy - Henryk Zieliński, Marek Dziewiecki, Dariusz Kowalczyk, w Niedzieli - Artur Stelmasiak, Wojciech Dudkiewicz. W tygodniku wydawanym przez kurię częstochowską odnotowano aż 11 tekstów, w których protagonistami byli oponenci środowiska LGBT+, niebędący autorami publikacji prasowej. Do nich należeli m.in. pan Tomasz K. - pracownik IKEI, który „wyraził swój sprzeciw wobec korporacyjnego przymusu promowania ideologii LGBT" (Stelmasiak 2019 b); 15-letni Jakub, który zablokował tzw. marsz równości w Płocku (Dudkiewicz 2019 a); abp Gądecki i prof. Capozzi - wskazujący konieczność przyjęcia jednoznacznej nieakceptującej postawy Kościoła wobec aktów profanacji dokonywanych przez przedstawicieli LGBT+ (Grabowski 2019).

Jedynie dwie publikacje w badanej cesze PROTAGONIŚCI zaklasyfikowano do kategorii „reprezentant środowiska LGBT+”, w których najważniejszymi postaciami w tekście były osoby wspierające ideologię LGBT. Należy tu wskazać o. Pawła Gużyńskiego, krytykującego abp. Jędraszewskiego za słowa homilii z 1 sierpnia 2019 r., piętnującej ideologię LGBT (Macura 2019), oraz Martę, katoliczkę i lesbijkę, z którą przeprowadzono wywiad na temat sytuacji osób należących do mniejszości seksualnych i doświadczających postaw homofobicznych (Wilczyński 2019 b).

Analiza prasoznawcza nie potwierdziła prawdziwości tez H3-H5. Na podstawie wyników badań stwierdzono, że tygodniki Niedziela, Gość Niedzielny i Idziemy przypisały środowisku LGBT+ cechy nietolerancyjne (36 publikacji spośród 46 zaliczono do kategorii „nietolerancyjna” w badanej cesze ŚRODOWISKO LGBT+), zaś przeciwnikom tychże społeczności przypisały cechy patriotyczne (31 publikacji) oraz dokonały jednoznacznej krytyki ideologii LGBT (46 publikacji). Tygodnik Powszechny zdystansował się od przypisania środowisku LGBT+ postaw nietolerancyjnych (nie odnotowano ani jednej publikacji przynależącej do kategorii „nietolerancyjna” w badanej cesze ŚRODOWISKO LGBT+), ich oponentom zaś imputował postawę homofobiczną (7 publikacji). Krakowski periodyk nie określił swojego stanowiska wobec ideologii LGBT - jedynie w 1 spośród 8 publikacji dokonał jej krytyki (Sikora 2019).

Analiza jakościowa dyskursu prowadzi do kilku ważnych spostrzeżeń. Odnotowano swoistą polaryzację stanowisk tygodników katolickich wobec środowiska LGBT+: z jednej strony tygodniki konserwatywne Niedziela, Gość Niedzielny i Idziemy, z drugiej zaś Tygodnik Powszechny. Dwubiegunowość narracyjna wyraziła się m.in. w odmiennej interpretacji dwóch wydarzeń: marszu równości w Białymstoku z 20 lipca 2019 r. oraz homilii abp. Jędraszewskiego wygłoszonej 1 sierpnia 2019 r. w Bazylice Mariackiej w Krakowie. Na łamach Niedzieli białostocki marsz równości został określony „objazdową prowokacją”, który z równością i tolerancją niewiele ma wspólnego i wpisuje się w serię prowokacji, szyderstw, bluźnierstw, profanacji i deptania największych świętości dla Polaków:

Obserwujemy przejawy skrajnej nietolerancji i dyskryminacji. Postulat równości odnosi się natomiast tylko do osób pod tęczowym sztandarem, bo każdy, kto 
przypomina o tym, że akty homoseksualne są grzechem, a homoskłonności nieuporządkowaniem i zaburzeniem osobowości, staje się celem zajadłych ataków (Stelmasiak 2019 c; LGBT+ nie uciszy mamy i taty).

Jak zauważa Marian Salwik,

w Białymstoku miało być homofobicznie i drastycznie. Gdyby kibole i nacjonaliści się nie pojawili, należałoby ich wymyślić. Gdyby kontrmanifestanci byli zbyt łagodni, należałoby ich sprowokować, a najlepiej dać się pobić (Salwik 2019).

Odmiennie białostocką paradę równości zrelacjonował Tygodnik Powszechny:

Podczas marszu równości w Białymstoku doszło do dantejskich scen: kibole i nacjonaliści zaatakowali przedstawicieli środowiska LGBT oraz wspierające ich osoby. Były ciosy, kopanie, plucie, wulgarne wyzwiska (Stankiewicz 2019).

Słowa homilii abp. Jędraszewskiego o „tęczowej zarazie” zostały zinterpretowane przez tygodniki prawicowo-konserwatywne w kluczu zagrożeń związanych z ideologią LGBT, przed którymi chce obronić metropolita krakowski. Jak zauważa Dariusz Kowalczyk,

dobrze, że nie brakuje biskupów, którzy z punktu widzenia Ewangelii i Tradycji Kościoła nie boją się publicznie mówić o złu modnych dzisiaj ideologii. Uważam, że mylą się ci, którzy radzą, by nie krytykować LGBT, że to nie jest wielki problem, że trzeba skupić się na pozytywnym przekazie. [...] obok prawdy o miłosierdziu i zbawieniu mamy prawdę o tym, co zagraża człowiekowi, o grzechu i złu (Kowalczyk 2019 c; Legutko 2019).

Tygodnik Niedziela wskazał listę hierarchów, którzy udzielili wsparcia abp. Jędraszewskiemu. Do nich należeli m.in. abp Hoser, kard. Grocholewski, abp Zvolensky, bp Bernacki, bp Veres (Wsparcie dla abp. Jędraszewskiego). Abp Gądecki zauważył, że szacunek dla osób przynależących do tzw. mniejszości seksualnych nie może prowadzić do akceptacji ideologii, która stawia sobie za cel przeprowadzenie rewolucji w zakresie społecznych obyczajów i międzyosobowych relacji (Gądecki 2019).

Z kolei Tygodnik Powszechny nie odniósł się do wypowiedzi abp. Jędraszewskiego. Pozostawił zatem otwartą drogę do krytyki poglądów i osoby hierarchy.

Krakowski periodyk wskazywał na słabość polskiego chrześcijaństwa, na brak wiary Kościoła hierarchicznego w siłę Dobrej Nowiny w konfrontacji z ideologią LGBT, na postawę agresji i homofobii wielu polskich katolików wobec uczestników marszów równości. Tygodnik Powszechny cytuje i omawia nacechowane homofobicznie podziękowanie duszpasterzy parafii św. Jadwigi w Białymstoku skierowane do oponentów marszu: 
Składamy wyrazy uznania i podziękowania tym wszystkim, którzy w ostatnim czasie, w jakikolwiek sposób włączyli się w obronę wartości chrześcijańskich i ogólnoludzkich, chroniąc nasze miasto, zwłaszcza dzieci i młodzież przed planowaną demoralizacją i deprawacją.

Zaś Non possumus wypowiedziane przez abp. Wojdę zostało zinterpretowane przez TP jako odrzucenie bliźniego (Sławek 2019).

Niedziela, Gość Niedzielny oraz Idziemy akcentowały kulturowy kontekst rewolucji obyczajowej, którą przynoszą reprezentanci środowiska LGBT+, oraz przypisywały im postawę nietolerancji, nawet jeśli własne działania legitymizowały „w imię tolerancji”, „w imię obrony godności człowieka”.

W Oświadczeniu Rady KEP ds. Apostolstwa Świeckich w sprawie narzucania ideologii LGBT, opublikowanym na łamach Niedzieli, można przeczytać m.in.:

Ogromnym niesmakiem, smutkiem, troską o przyszłość, a nawet poczuciem zagrożenia napawają zwyczajnych ludzi zachowania i słowa aktywistów tego środowiska [LGBT] i wspierających je dziennikarzy. Niby walczą o wolność, tolerancję i szacunek, ale właśnie bez tolerancji, z pogardą wobec myślących inaczej i z agresją (Dec 2019).

Jak zauważa Henryk Zieliński,

aktywiści LGBT nie stronią od przemocy nie tylko prawnej i kulturowej, ale również fizycznej. W Polsce szydzą z katolickich sakramentów pod ochroną policji. Za odmowę włączenia się w propagandę LGBT, na wniosek Rzecznika Praw Obywatelskich (sic!) ludzie są ciągani po sądach (drukarz z Łodzi), tracą pracę (pan Tomasz z IKEA), z aktorami zrywane są kontrakty (Redbad Klijnstra, Jarosław Jakimowicz) (Zieliński 2019 b; Kowalczyk 2019 b).

\section{W opinii Tomasza Krzyżaka}

strategia środowisk LGBT i popierających ich polityków sprowadza się dziś do ciągłego podsycania emocji i dbania o to, by temat nie umarł. Chodzi o to, by przyzwyczaić społeczeństwo do swoich postulatów (Krzyżak 2019).

Z kolei Piotr Legutko wskazuje promowanie fałszywej antropologii jako główną przyczynę kryzysu kultury współczesnej (Legutko 2019; Grajewski 2019).

W katolickich tygodnikach prawicowo-konserwatywnych uwyraźniono argumenty, dlaczego środowiska katolickie nie akceptują ideologii LGBT - jest bowiem wymierzona w ludzką godność, pozostaje sprzeczna z prawem natury oraz przynosi dewastację duchową i materialną człowiekowi:

LGBTQ to nie biedne, prześladowane osoby, które domagają się tolerancji, ale silna, dofinansowywana z różnych stron ideologia, która stoi na czele 
neomarksistowskiej rewolucji chcącej zmienić znaczenie podstawowych pojęć, jak płeć, małżeństwo, rodzina, dzieci. Przy czym działacze tej ideologii są coraz bardziej agresywni i nietolerancyjni. Szczególnie agresywni są wobec Kościoła katolickiego (Kowalczyk 2019 a; por. także Dziewiecki 2019 a; Kowalczyk 2019 d; Dziewiecki 2019 b; Kabiesz 2019).

W publikacjach Tygodnika Powszechnego kwestia oceny ideologii LGBT z punktu widzenia katolickiej wiary została zupełnie pominięta.

Dwubiegunowość narracyjna w analizowanych publikacjach prasowych tygodników wyraziła się także w odmiennym wskazaniu granic między profanum i sacrum. Dla publicystów Niedzieli, Gościa Niedzielnego i Idziemy umieszczanie na wizerunku ikony Matki Boskiej Częstochowskiej aureoli tęczy, parodiowanie Mszy św. i procesji Bożego Ciała stanowi bluźnierstwo i obrazę uczuć religijnych (Zieliński 2019 a). Tygodnik Powszechny potraktował kwestię symboli religijnych w odmienny sposób. W opinii Piotra Sikory „nie ma profanacji, jeśli przekształcenie symbolu jest zgodne z pierwotnym przesłaniem danych symboli, z treścią wiary, którą mają ożywić" (Sikora 2019). Zdaniem publicysty domalowanie Maryi i Jezusowi tęczowego nimbu byłoby próbą zwrócenia uwagi, że Bóg jest po stronie odrzuconych i cierpiących z powodu agresji wobec osób LGBT+, ich poniżania i wykluczania (Sikora 2019). Odmienną perspektywę oceny działań aktywistów LGBT+ zaprezentowały tygodniki prawicowo-konserwatywne. Tytułem przykładu można wskazać wypowiedź Marka Dziewieckiego:

Aktywiści LGBT+ nie organizują marszów równości, gdyż takie marsze w naszym państwie są zupełnie zbędne. Organizują natomiast marsze nienawiści i pogardy, w czasie których publicznie kpią sobie z Boga, z Biblii, z chrześcijan, z Eucharystii, ze świętych, z małżeństwa i rodziny, z wychowania, z czystości, z płodności i z płci, z kapłanów i sióstr zakonnych, z godności człowieka. W przestrzeni publicznej zachowują się obscenicznie - na oczach dorosłych, którzy sobie tego nie życzą, a także na oczach dzieci. Afiszują się z plakatami i napisami, które zawierają obsceniczne rysunki i niecenzuralne słowa (Dziewiecki 2019 a).

Autor odnotował również stosowanie odmiennych metafor mediatyzacji w odniesieniu do przedstawicieli Kościoła hierarchicznego. W przypadku Niedzieli, Gościa Niedzielnego oraz Idziemy można wskazać następujące: oponenci środowiska LGBT+ to obrońcy wiary i wartości chrześcijańskich, biskupi - patrioci. W Tygodniku Powszechnym zaś dominowała metafora krytyków środowiska LGBT+ jako homofobów.

Rozmówczyni publicysty TP Przemysława Wilczyńskiego, określona jako „Marta, katoliczka i lesbijka", stwierdza, że

Kościół nie chce wejść w nasz świat, a jeśli już, to jako kolonizator [...]. Ja bym chciała, żeby mój Kościół przestał mnie demonizować. Żeby o. Leon Knabit nie zrównywał homoseksualizmu z pedofilią. Żeby mnie nie ranił, powielając 
stereotypy o tym, że osoba odmienna nie wierzy w Boga, za to nastawiona jest na osiąganie maksimum przyjemności (Wilczyński 2019 b).

Tygodnik Powszechny w odróżnieniu od pozostałych analizowanych tytułów prasowych eksponuje zjawisko polityzacji religii, tj. wykorzystanie dyskursu na temat środowiska LGBT+ przez polityków Prawa i Sprawiedliwości na użytek kampanii parlamentarnej, prezentujących się jako jedynych obrońców „naszej chrześcijańskiej kultury” (Sikora 2019). Andrzej Stankiewicz zauważa, że „PiS jest na najlepszej drodze, żeby wykorzystać białostockie ekscesy do swych politycznych, wyborczych planów" (Stankiewicz 2019). Z kolei Przemysław Wilczyński zwraca uwagę na instrumentalne wykorzystanie zajść w Białymstoku przez ministra Piontkowskiego do wsparcia tezy o „seksualizacji dzieci” przez osoby reprezentujące mniejszości seksualne (Wilczyński 2019 a).

Tygodniki prawicowo-konserwatywne nie powiązały natomiast krytyki ideologii LGBT ze wsparciem politycznym udzielonym Prawu i Sprawiedliwości ani też z szeroko rozumianym kontekstem wyborczym.

\section{Podsumowanie}

Kategorie patriotyzmu, homofobii i nietolerancji odgrywają istotną rolę w kształtowaniu wizerunku środowiska LGBT+ w polskich tygodnikach katolickich. W tytułach o profilu prawicowo-konserwatywnym odnotowuje się linię zbieżną z nauczaniem Kościoła w kwestii ideologii LGBT, a jednocześnie uwydatnia się postawę nietolerancji ze strony osób należących do mniejszości seksualnych wobec katolików. Reprezentujący tzw. katolicyzm otwarty Tygodnik Powszechny uwyraźnił postawy homofobiczne wśród katolików, jednocześnie nie zajął stanowiska wobec ideologii LGBT w kontekście nauczania Kościoła. Krakowski periodyk jako jedyny $\mathrm{z}$ analizowanych tytułów prasowych powiązał temat LGBT z polityką, tj. z instrumentalnym wykorzystaniem w kampanii wyborczej instytucji eklezjalnej.

Nie budzi zdziwienia, że w prasie katolickiej obficie cytowano doktrynę Kościoła katolickiego w przedmiotowej kwestii. Zabrakło jednak jakiegokolwiek odniesienia do stanu wiedzy psychologicznej i medycznej dotyczącej zagadnienia orientacji seksualnej, choćby naukowych ustaleń uznających równoprawność orientacji hetero-, homo - i biseksualnej czy też prawo osób transpłciowych do samostanowienia (Russell 2011, s. 376-393; Falomir Pichastor \& Hegarty 2014, s. 731-751).

Publikacje prasowe Niedzieli, Gościa Niedzielnego i Idziemy w kontekście podjętego tematu zaproponowały narrację antagonistyczną i polaryzującą, przybierającą szaty manichejskiego sporu dobra ze złem, wojny dwóch światów, bez możliwości dialogu, skazanych na wzajemne wyniszczenie (Ziółkowski 2017, s. 92-93). 


\section{Bibliografia}

\section{Artykuły w czasopismach}

Augustyn J. (2007). Homoseksualizm w oczach Kościoła. Znak, nr 630, s. 10-15.

Bujak J. (2014). Stanowisko III Nadzwyczajnego Synodu Biskupów o Rodzinie na temat homoseksualizmu na tle ideologii gender i protestów przeciw „małżeństwu dla wszystkich”. Studia Paradyskie, nr 24, s. 69-96.

Czupryński W. (2019). Wychowanie w rodzinie w zderzeniu z ideologią gender. Studia Ełckie, nr 21 (4), s. 455-469.

Delong M. (2007). Środowisko Tygodnika Powszechnego wobec demokracji, liberalizmu i kapitalizmu po 1989 roku. Polityka i Społeczeństwo, nr 4, s. 56-64.

Falomir Pichastor J.M., \& Hegarty P. (2014). Maintaining distinctions under threat: Heterosexual men endorse the biological theory of sexuality when equality is the norm. British Journal of Social Psychology, vol. 53 (4), s. 731-751.

Gegenfurtner A., Gebhardt M. (2017). Sexuality education including lesbian, gay, bisexual, and transgender (LGBT) issues in schools. Educational Research Review, vol. 22, s. 215-222.

Glombik K. (2013). Tolerancja jako postawa moralna. Studia Oecumenica, nr 13, s. 113-126.

Graff A. (2014). Report from the gender trenches: War against 'genderism'in Poland. European Journal of Women's Studies, vol. 21 (4), s. 431-435.

Herek G.M. (2007). Confronting sexual stigma and prejudice: Theory and practice. Journal of Social Issues, vol. 63 (4), s. 905-925.

Kinowska Z. (2012). Kondycja społeczeństwa obywatelskiego w Polsce. Infos. Zagadnienia społeczno-gospodarcze, nr 22, s. 1-4.

Korolczuk E. (2019). The fight against 'gender'and 'LGBT ideology': new developments in Poland. European Journal of Politics and Gender, vol. 3 (1), s. 165-167.

Leśniczak R. (2018). Polish Catholic press and political communication of the Church on the basis of the 2000-2015 presidential election. Political Preferences, nr 18, s. 37-56.

Leśniczak R. (2017). Wizerunek prezydenta elekta Andrzeja Dudy w polskich tygodnikach katolickich Gość Niedzielny i Niedziela. Politeja - Pismo Wydziału Studiów Międzynarodowych i Politycznych Uniwersytetu Jagiellońskiego, nr 14 (48), s. 299-318.

Madžarević G., Soto-Sanfiel M.T. (2018). Positive representation of gay characters in movies for reducing homophobia. Sexuality \& Culture, vol. 22 (3), s. 909-930.

Müller A. (2018). Beyond 'invisibility': queer intelligibility and symbolic annihilation in healthcare. Culture, Health \& Sexuality, vol. 20 (1), s. 14-27.

Nadar S., Klinken van A. (2018). "Queering the Curriculum": Pedagogical Explorations of Gender and Sexuality in Religion and Theological Studies. Journal of Feminist Studies in Religion, vol. 34 (1), s. 101-109.

Podemski K. (2014). Społeczeństwo obywatelskie w Polsce 25 lat po wielkiej zmianie. Ruch Prawniczy, Ekonomiczny i Socjologiczny, nr 2, s. 89-109.

Przesmycki P. (2008). Patriotyzm w nauczaniu Kościoła katolickiego. Annales. Etyka w Życiu Gospodarczym, nr 11, s. 195-203.

Russell G.M. (2011). Motives of heterosexual allies in collective action for equality. Journal of Social Issues, vol. 67 (2), s. 376-393. 
Tasak A. (2014). Katolicyzm a liberalizm. Recepcja liberalizmu na łamach współczesnej, polskiej prasy katolickiej (wybrane zagadnienia). Polityka i Społeczeństwo, nr 4 (12), s. 70-85.

Tytko M. (2013). Teoria patriotyzmu i terminologia patriologiczna: (pedagogika kultury narodowej). Pedagogia Ojcostwa, nr 6 (1), s. 213-223.

Uryga D. (2018). Ruch społeczny na rzecz praw osób LGBT+ Między rodziną a szkołą. Pedagogika Społeczna, nr 4 (70), s. 327-343.

Ziółkowski J. (2017). Wróg w politycznych narracjach antagonizmu manichejskiego. Wrocławskie Studia Politologiczne, nr 22, s. 92-107.

\section{Książki}

Bilić B., Kajinić S. (Eds.) (2016), Intersectionality and LGBT Activist Politics: Multiple Others in Croatia and Serbia. London.

Hall D. (2016). W poszukiwaniu miejsca. Chrześcijanie LGBT w Polsce. Warszawa.

Kongregacja Nauki Wiary (1992). Katechizm Kościoła Katolickiego. Rzym.

Kościółek J., Bulandra A., Zimnoch M. (2015). Mowa nienawiści w przestrzeni publicznej: raport z badań prasy w 2014 roku. Kraków.

Pisarek W. (1983). Analiza zawartości prasy. Kraków.

Skorowski H. (1996). Moralność społeczna. Wybrane zagadnienia z etyki społecznej, gospodarczej i politycznej. Warszawa.

\section{Rozdziały w dziele zbiorowym}

Antoszewski A. (2004). Demokracja. W: A. Antoszewski, R. Herbut (red.). Leksykon politologii (s. 66). Wrocław.

Antoszewski A. (2000). Społeczeństwo obywatelskie a proces konsolidacji demokracji. W: A. Czajowski, L. Sobkowiak (red.). Studia z teorii polityki, t. 3 (s. 9-15). Wrocław.

Mautner G. (2011). Analiza gazet, czasopism i innych mediów drukowanych. W: R. Wodak, M. Krzyżanowski (red.). Jakościowa analiza dyskursu w naukach społecznych (s. 51-85). Warszawa.

Nikitorowicz J. (2013). Dylematy patriotyzmu, nacjonalizmu i ustawicznie kształtującej się tożsamości. Wprowadzenie do książki. W: tenże (red.). Patriotyzm i nacjonalizm. Ku jakiej tożsamości kulturowej? (s. 14-26). Kraków.

Pokorna-Ignatowicz K. (2014). „Ideologia gender” i Konwencja o zapobieganiu i zwalczaniu przemocy wobec kobiet i przemocy domowej w polskich mediach katolickich. W: A. Frątczak (red.). Gender mainstriming w polskim dyskursie medialnym na przykładzie debaty nad Konwencją o zapobieganiu i zwalczaniu przemocy wobec kobiet i przemocy domowej (s. 194-251). Kraków.

Sienkiewicz E. (2007). Godność człowieka i narodu u podstaw współczesnego patriotyzmu polskiego. W: B. Bardziejewski (red.). Dociekając prawdy o naszej tożsamości. Godność człowieka i narodu u podstaw współczesnego patriotyzmu polskiego (s. 35-54). Poznań.

Szwed A., Zielińska K. (2017). A War on Gender? The Roman Catholic Church's Discourse on Gender in Poland. W: S. Ramet, I. Borowik (red.). Religion, Politics, and Values in Poland (s. 113-136). New York.

Wodak R. (2011). Wstęp: Badania nad dyskursem - ważne pojęcia i terminy. W: R. Wodak, M. Krzyżanowski (red.). Jakościowa analiza dyskursu w naukach społecznych (s. 11-48). Warszawa. 


\section{Artykuły na stronie internetowej}

Gądecki S. (8.08.2019). Oświadczenie ws. LGBT+ [https://ekai.pl/szacunek-do-osob-lgbt-nie-moze-prowadzic-do-akceptacji-ideologii/; 17.03.2020].

Przeciszewski M. (30.07.2019). Nauczanie Kościoła na temat homoseksualizmu [https://ekai.pl/ nauczanie-kosciola-na-temat-homoseksualizmu-2/; 17.03.2020].

Rada ds. Społecznych KEP. (14.03.2017). Chrześcijański kształt patriotyzmu [https://episkopat. $\mathrm{pl} /$ chrzescijanski-ksztalt-patriotyzmu-dokument-konferencji-episkopatu-polski-przygotowany-przez-rade-ds-spolecznych/; 17.03.2020].

\section{Artykuły prasowe}

\section{Gość Niedzielny}

Grajewski A. (2019). Nie możemy być bierni. Gość Niedzielny, nr 33, s. 20-21.

Kabiesz E. (2019). Ania z tęczowego wzgórza. Gość Niedzielny, nr 14, s. 20-22.

Kowalczyk D. (2019). „Cywilizacja” tęczowej aureoli. Gość Niedzielny, nr 21, s. 38.

Krzyżak T. (2019). Przemyślana strategia. Gość Niedzielny, nr 33, s. 36-37.

Legutko P. (2019). Kto nie z nami. Gość Niedzielny, nr 33, s. 34-35.

Łoziński B. (2019). Gender nie pokona teologii ciała. Gość Niedzielny, nr 15, s. 30-31.

Łoziński B. (2019). Środowiska LGBT cenzurują. Gość Niedzielny, nr 32, s. 7.

Macura A. (2019). Pokuta o. Gużyńskiego. Gość Niedzielny, nr 33, s. 6.

Nowak A. (2019). Hipokryzja. Gość Niedzielny, nr 20, s. 74.

\section{Tygodnik Powszechny}

Boniecki A. (2019). Boniecki: Zastanawia mnie brak wiary. Tygodnik Powszechny, nr 31, s. 3.

Duda S. (2019). Antyklerykalizm nie wystarczy. Tygodnik Powszechny, nr 32, s. 36-39.

Rosiak D. (2019). Bądźmy niekonsekwentni. Tygodnik Powszechny, nr 33, s. 22-24.

Sikora P. (2019). Nie profanuj bliźniego swego. Tygodnik Powszechny, nr 20, s. 37-39.

Sławek T. (2019). Rozum, furia i wiara. Tygodnik Powszechny, nr 31, s. 34-37.

Stankiewicz A. (2019). Wymarzona wojna Prezesa. Tygodnik Powszechny, nr 31, s. 26-28.

Wilczyński P. (2019). Ministerstwo głupich słów. Tygodnik Powszechny, nr 31, s. 27-28.

Wilczyński P. (2019). Żebyś to w sobie podważała. Tygodnik Powszechny, nr 26, s. 34-39.

\section{Idziemy}

Dziewiecki M. (2019). Marsze nienawiści. Idziemy, nr 31, s. 5.

Dziewiecki M. (2019). Standardy WHO a kodeks karny. Idziemy, nr 15, s. 20-21.

Gądecki S. (2019). W sprawie LGBT. Idziemy, nr 33, s. 5.

Jędraszewski M. (2019). Nie wolno się poddawać. Idziemy, nr 35, s. 38-39.

Komorek M. (2019). Jesteśmy za. Idziemy, nr 13, s. 17.

Kowalczyk D. (2019). LGBTQ, polityka, Kościół. Idziemy, nr 23, s. 9.

Kowalczyk D. (2019). Odważny abp Wojda. Idziemy, nr 31, s. 9.

Kowalczyk D. (2019). Standardy „pełne szacunku”. Idziemy, nr 33, s. 9.

Kowalczyk D. (2019). Totalitaryzm i nihilizm. Idziemy, nr 30, s. 9.

Meetschen A. (2019). Czy mówisz po gendersku? Idziemy, nr 13, s. 7.

Meetschen A. (2019). Dobro dzieci według UNICEF. Idziemy, nr 28, s. 8. 
(2019). LGBT+ nie uciszy mamy i taty. Idziemy, nr 14, s. 5.

(2019). Na tak. Idziemy, nr 13, s. 14.

Odrobińska M. (2019). Szkoła bez LGBT+. Idziemy, nr 35, s. 36-37.

Sułek-Kowalska B. (2019). Przed czym się chronić? Idziemy, nr 14, s. 24.

(2019). Wsparcie dla abp. Jędraszewskiego. Idziemy, nr 34, s. 37.

Zatyka M. (2019). Hiszpania w stylu gender. Idziemy, nr 14, s. 20-21.

Zieliński H. (2019). Abdykacja? Idziemy, nr 31, s. 3.

Zieliński H. (2019). Agresorzy czy ofiary? Idziemy, nr 33, s. 3.

Zieliński H. (2019). Bez echa. Idziemy, nr 14, s. 3.

Zieliński H. (2019). Czyja tęcza? Idziemy, nr 20, s. 10-11.

\section{Niedziela}

Dec I. (2019). Nie rozpalajcie stosów. Oświadczenie Rady KEP ds. Apostolstwa Świeckich w sprawie narzucania ideologii LGBT. Niedziela, nr 29, s. 14-15.

Dokowicz L. (2019). Postawić krzyż w centrum życia. Niedziela, nr 33, s. 14.

Dudkiewicz W. (2019). Jakub blokuje LGBT. Niedziela, nr 34, s. 38-39.

Dudkiewicz W. (2019). Kościół potępia zło. Niedziela, nr 33, s. 6.

Gądecki S. (2019). Trzeba jasno powiedzieć dość! Niedziela, nr 29, s. 10-13.

Grabowski J. (2019). Gdy katolik ma dość. Niedziela, nr 29, s. 3.

Rozpiątkowski P. (2019). Księża na celowniku. Niedziela, nr 32, s. 31.

Rozpiątkowski P. (2019). Niebezpieczna propaganda. Niedziela, nr 29, s. 16-17.

Salwik M. (2019). Nieudana prowokacja w Białymstoku. Niedziela, nr 31, s. 29.

Scandroglio T. (2019). Jak reżyseruje się „marsze równości”. Niedziela, nr 33, s. 38-39.

Stelmasiak A. (2019). Co powiedział abp Jędraszewski? Niedziela, nr 32, s. 7.

Stelmasiak A. (2019). IKEA prześladuje katolików. Niedziela, nr 27, s. 7.

Stelmasiak A. (2019). Objazdowa propaganda. Niedziela, nr 31, s. 28.

Tomoń S. (2019). Nie milczmy, gdy trzeba mówić. Niedziela, nr 30, s. 8.

wd (2019). Nie dla homoterroru. Niedziela, nr 18, s. 6.

wd (2019). Parada bluźnierców. Niedziela, nr 24, s. 6.

\section{STRESZCZENIE}

Celem badań było określenie wizerunku środowiska LGBT+ w ogólnopolskich tygodnikach katolickich, szczególnie w kontekście patriotyzmu i homofobii przypisywanych oponentom LGBT+. Ważny kontekst analizy stanowiły marsze równości w 2019 r. Zamiarem autora było również ustalenie, która z postaw wobec zasady równości każdego człowieka wobec prawa niezależnie od jego orientacji seksualnej (akceptacji vs. krytyki), dominowała w poszczególnych tytułach prasowych. Materiał badawczy stanowiły drukowane wersje tygodników Niedziela, Gość Niedzielny, Idziemy, Tygodnik Powszechny. Analizą objęto teksty dotyczące tematyki środowiska LGBT+, w których zawarte było przynajmniej jedno z następujących słów kluczowych: „LGBT”; „marsz równości”; „parada równości”, i które zostały opublikowane w okresie 31.03.2019-30.09.2019. Autor posłużył się metodą analizy zawartości prasowej oraz metodą jakościowej analizy dyskursu. Tygodniki Niedziela, Gość Niedzielny i Idziemy 
przypisały środowisku LGBT+ cechy nietolerancyjne, zaś ich przeciwnikom - cechy patriotyczne oraz dokonały jednoznacznej krytyki ideologii LGBT. Tygodnik Powszechny zdystansował się od przypisania środowisku LGBT+ postaw nietolerancyjnych, ich oponentom zaś imputował postawę homofobiczną. Badania dowiodły odmiennego wizerunku prasowego osób należących do mniejszości seksualnych w katolickich tygodnikach prawicowo-konserwatywnych i reprezentujących tzw. kościół otwarty. Dwubiegunowość narracji wyraziła się w analizowanych tytułach prasowych m.in. w odmiennym rozumieniu kategorii profanum/ sacrum, symboli religijnych, kulturowej rewolucji obyczajowej i odmiennym stosowaniu metafor mediatyzacji wobec krytyków środowiska LGBT+.

Słowa kluczowe: patriotyzm, homofobia, nietolerancja, wizerunek, środowisko LGBT+, prasa katolicka 